\title{
Endophytic Fungi in Species of Artemisia
}

\author{
Andreea Cosoveanu * (i) and Raimundo Cabrera \\ Facultad de Ciencias-Sección Biología, Dept. Botanica, Ecologia \& Fisiologia Vegetal, \\ Universidad de La Laguna, Apdo. 456, 38200 La Laguna, Spain; rcabrera@ull.edu.es \\ * Correspondence: andreeacosoveanu@gmail.com; Tel.: +34-922-318348
}

Received: 8 March 2018; Accepted: 28 April 2018; Published: 1 May 2018

\begin{abstract}
The genus Artemisia, a collection of 400 hardy herbaceous plant and shrub species, is an important resource contributing to chemistry, medicine, agriculture, industry, and ecology. Its communities of endophytic fungi have only recently begun to be explored. Summarized from studies conducted on the fungal endophytes in Artemisia species, both fungal phylogenetic diversity and the associated bioactivity was examined. Isolations from 14 species of Artemisia have led to 51 genera of fungal endophytes, 28 families, and 18 orders. Endophytes belonged mainly to Ascomycota, except for two taxa of Cantharellales and Sporidiobolales, one taxon of Mucoromycota, and one species of Oomycota. The mostly common families were Pleosporaceae, Trichocomaceae, Leptosphaeriaceae, and Botryosphaeriaceae (relative abundance $=14.89,8.51,7.14$ and 6.38, respectively). In the search for bioactive metabolites, 27 novel compounds were characterized and 22 metabolites were isolated between 2006 and 2017. The first study on endophytic fungi isolated from species of Artemisia was published but 18 years ago. This summary of recently acquired data illustrates the considerable diversity of biological purposes addressed by fungal endophytes of Artemisia spp.
\end{abstract}

Keywords: medicinal plants microbiome; phylogeny; bioactivity; rare fungal species

\section{State of the Art}

Artemisia is a genus of plants highly valued as a source of metabolites useful in, for example, medicine and biopesticides. Phytochemical analyses showed the main compounds in A. vulgaris to be flavones, flavone glycosides, flavanones, flavonols, flavonol glycosides, and volatile compounds such as $\alpha$-pinene, camphor, camphene, germacrene D, 1,8-cineole, $\beta$-caryophyllene, $\alpha$-thujone, 1,8-cineole, sabinene, $\beta$-thujone, $\beta$-caryophyllene oxide, neryl 2 -methylbutanoate, $\beta$-eudesmol, and bornyl 3-methylbutanoate [1-4]. A review on the chemistry of 15 species of Artemisia resulted in 839 compounds with mainly terpenoids, flavonoids, coumarins, caffeoylquinic acids, sterols, and acetylens [5]. Biological activity was detected in a series of compounds such as eupatilin (anticancer) [5]; artemisolide (anti-inflammatory) [6]; $\alpha$-thujone (toxicity against adult mites) [7]; chamazulene, 1,8-cineole, and $\beta$-caryophyllene (toxicity against the cigarette beetle) [8]; luteolin (anti-inflammatory, anticancer, antimicrobial, antioxidant) [9]; and eriodictyol (anti-inflammatory properties, beneficial effect in treatment of diabetic retinopathy, emmenagogue) [10-12]. Also, Artemisia annua remains the main commercial source for artemisinin [13]. Nevertheless, essential oils; organic fractions of hydrolate byproducts; and extracts of various species of Artemisia, wild and domesticated (A. absinthium, ${ }^{\circledR}$ Cvar. Candial, Spain), proved to have potential in further commercial use with effects such as anti-toxoplasmosis [14], anti-mosquitoes [15], nematicidal [16,17], larvicidal against Pieris brassicae [18] and reduction of the longevity and fecundity of Tetranychus urticae [19]. Extensive reviews describe (i) the conservation status, phytochemistry and biological activities of the Artemisia genus in the Iberian Peninsula and two Macaronesian archipelagos [20]; (ii) the chemical composition and biological activity of essential oils in various 
species of Artemisia [6] and (iii) the phytochemistry and pharmacological and biotechnological potential of A. vulgaris [4].

A survey of the literature shows that this genus has engaged many researchers, with 12,300 publications in the Scopus library, almost double that of the genus Taxus (Scopus library-6593 entries). Although Taxus is associated with US\$1B per annum worth of sales of the cytostatic drug taxol, the fact that Artemisia is a medicinal plant genus with 474 accepted species [21] and multiple uses may explain its relative dominance of the literature. The present survey also reveals the dominance of the plant-focused research rather than that devoted to the plant-endophyte associations. As may be observed in Figure 1, whether we consider one or all databases, the numbers show that up to $0.9 \%$ of the number of the publications containing "Artemisia" as a keyword include "endophyte" as a keyword (Scopus-88 entries, 0.7\%; PubMed-34 entries, 0.9\%; and CAB Direct-two entries, $0.45 \%$ ). For Taxus and endophyte, the comparative number of publications was up to $4.28 \%$ (Scopus-160 entries, $2.42 \%$; PubMed-88 entries, $4.28 \%$; and CAB Direct—three entries, $3.37 \%$ ).

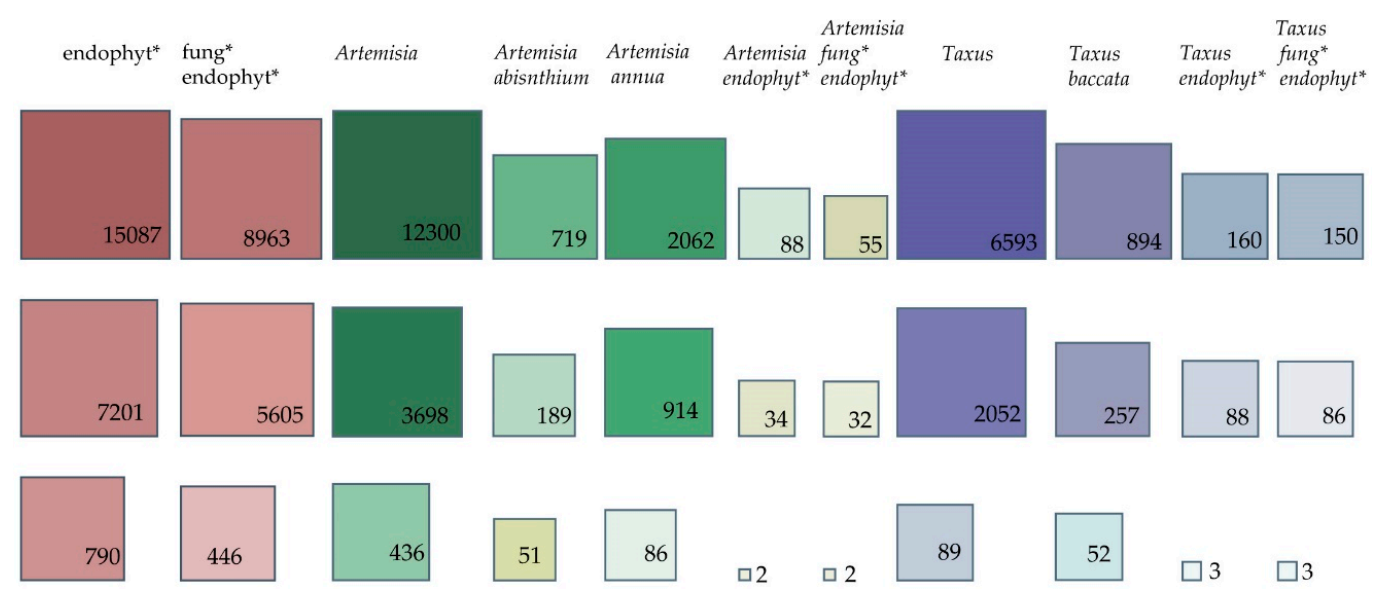

Figure 1. Survey of the literature in databases (Scopus—-first upper line of squares; PubMed—middle line with squares; and CAB Direct-bottom line with squares) with indexed keywords related to host plants and endophytes. ${ }^{*}=$ Keywords were used as shown in the figure except for the PubMed database, where the use of wildcards is irrelevant in a standard search as it uses only the root of the term for the generating hits. The search was performed for the title, abstract and keywords or descriptors, where possible (i.e., in Scopus and CAB Direct). Values in squares are the number of publications. Squares are proportional to the number of publications. Interpretation of squares scaling was calculated per group of data as follows: cluster 1-endophytes and fungal endophytes, cluster 2-Artemisia and related keywords, cluster 3-Taxus and related keywords; the highest number of publications per each cluster was considered $100 \%$. Transformation to $\log _{10}$ was performed to reduce the skewness and facilitate interpretation of the squares.

Comparing the keywords "Artemisia endophytes" and "Artemisia fungal endophytes" in Scopus, the number of publications containing "Artemisia fungal endophytes" represents $62.5 \%$ of the number of publications containing "Artemisia endophytes", except in CAB Direct and PubMed where no relevant difference was observed. We might extrapolate that the rest of $37.5 \%$ of the publications regard bacterial endophytic communities in Artemisia. Similar numbers are shown for the comparison within the Taxus genus.

Artemisia annua was highly rated with three times more publications than for Artemisia absinthium (Scopus library-2062 hits versus 719, respectively). These values reflect the great interest in artemisinin, produced by Artemisia annua, which is an important drug used to treat malaria and cancer. Various fungi have been investigated as elicitors or direct producers of artemisinin. Up-to-date information in Table 2 summarises the findings from research into endophytes of Artemisia endophytic communities. 


\section{Artemisia Fungal Endophyte Identification and Diversity}

Overall, the identification of the fungal endophytes in Artemisia spp. is made based on morphological characterization and molecular analysis using (i) 28S ribosomal DNA spanning domains D1 and D2 and (ii) nuclear ribosomal DNA sequences, including both the internal transcribed spacers (ITS1 and ITS2) and the 5.8S gene region. Three studies investigated the phylogenetic analysis of the Artemisia spp. fungal endophytes [22-24]. Although the number of studies is small, interesting facts are brought to light in terms of diversity and plant colonization. For Artemisia annua, the endophytic fungal infection frequency was slightly higher in the roots of cultivated plants $(20.9 \%)$ than in the roots of wild plants (16.7\%) [25]. Moreover, the authors showed that the latter roots harboured more rich fungal taxa, which supports the hypothesis that wild plant species are predisposed to be hosts for rich and novel mycoflora $[26,27]$. The differences can be extended to fungal pathogens, where $55 \%$ of the fungal communities in wild fruits were not present in their homologous cultivated species [28]

Strains of Aplosporella prunicola, Chaetomium sp., Macrophomina phaseolina, Nectria mauritiicola, Neofusicoccum australe, Pestalotiopsis sp., and Stachybotrys longispora were isolated only from one nutrient medium and only from Artemisia thuscula collected in Tenerife island, in a study comparing La Palma and Tenerife in the Canary Islands [24]. Diversity indices showed that plant individuals collected in La Palma had higher diversity values in terms of species richness, diversity of taxa, abundance of rare species, and species evenness. The study indicates the relevance of the exploration of different plant tissues and usage of wider number of growth media to obtain diversity. Comparing arbuscular mycorrhizal fungi (AMF) with dark septate endophytes (DSE) and other types of endophytic fungi (EF), a low colonization frequency of AMF was detected in roots, while EF were more frequently found in Artemisia annua [25].

Endophytic fungi were isolated from Artemisia argyi, and Pleosporales was found to be the most represented group, with three species of Alternaria present [29]. It is worth mentioning that Qian et al. [29] reported the presence of Rhodotorula sp. and Fusarium sp. in Artemisia argyi. Myrchiang et al. [30] investigated the endophytic fungi associated with Artemisia nilagirica, and isolated among the dominant clade of Ascomycota, one strain of Pythium intermedium (Oomycota) and one strain of Rhizopus oryzae (Zygomycota). Comparing the colonization of three plant parts (i.e., root, stem, and leaf), the authors found that the highest diversity was in the roots (i.e., 14 species), followed by stems (i.e., 10 species), and least in the leaves (i.e., six species). Similarly, in Artemisia thuscula were isolated 29 distinct morphotypes: 20 from roots, seven from stems, and two from leaves [31]. In addition, Myrchiang et al. [30] observed that from all fungal endophytic species, only Phoma eupyrena was found to be most dominant in all plant samples; the other species having a certain preference for one or a maximum of two plant parts. Huang et al. [22] classified 108 fungal isolates obtained from three medicinal plant species, Artemisia capillaris, Artemisia indica, and Artemisia lactiflora, using morphological identification. In total, 42 isolates were obtained from the host Artemisia capillaris (five isolates from leaves, 15 isolates from stems, and 22 isolates from inflorescences). In total, 39 strains were isolated from the host Artemisia indica (18 isolates from leaves and 21 from stems). Twenty-seven fungal strains were isolated from the host Artemisia lactiflora (16 isolates from leaves and 11 from stems). Among them, Alternaria, Colletotrichum, and Phomopsis were common, especially Alternaria spp. (25\% relative isolation frequency) and Colletotrichum spp. (20.4\% relative isolation frequency). One strain was isolated from the stems of Artemisia capillaris and was similar to Drechslera sp. Among the three plant hosts, the highest endophytic colonization rate occurred in Artemisia capillaris, which had the highest fungal diversity. Five fungal isolates belonging to Aureobasidium pullulans, Ephelis, Pestalotiopsis, and Pleosporaceae were only obtained from Artemisia capillaris. Xylaria species appeared to be the most common endophytic fungi in Artemisia indica.

Seven Artemisia species were sampled in two locations (Qichun and Wuhan), and 21 fungal endophytic species were isolated from stems and identified as Diaporthe, Colletotrichum, Nigrospora, Botryosphaeria, Aspergillus, Penicillium, Neofusicoccum, Cercospora, Rhizoctonia, Alternaria, and Curvularia [23]. The highest incidences of colonization frequency per plant were attributed 
to Nigrospora sphaerica in Artemisia sp., Nigrospora oryzae in Artemisia argyi, Alternaria alternata in Artemisia subulata and Artemisia tangutica, and Botryosphaeria dothidea in Artemisia lavandulifolia. This was the first report of Nigrospora, Neofusicoccum and Curvularia species in Artemisia spp. As for plant species specificity, only Nigrospora sphaerica, Nigrospora oryzae and Alternaria alternata were present in various plants; except for Cochliobolus geniculatus, isolated from Artemisia brachyloba and Artemisia argyi. Thus, few endophytic fungi were found to be entirely restricted to particular plant species, but significant differences were found in the frequency of colonization of individual morphotaxa. The study highlighted the Alternaria genus as the dominant one, having the reputation of being one of the cosmopolitan endophytes reported. Nigrospora displayed the second highest rate of occurrence in this analysis, followed by Botryosphaeria whose incidence has been described more in woody plants.

A heat map table (Table 1) describes the relative abundance of genera, families and orders of the endophytic mycopopulation of Artemisia species. The most isolated taxa belong to Pleosporales, Hypocreales, Xylariales, Botryosphaeriales, and Eurotiales (relative abundance $\%=25,17.31,9.62,7.69$, and 7.69 , respectively). Yet these numbers do not reflect the diversity of the families included, as Pleosporales and Hypocreales have been found each with taxa belonging to four families while Hypocreales and Xylariales were found with four and two families, respectively. Phomopsis, Alternaria and Penicillium were the most isolated genera (relative abundance $\%=36.36,36.36$ and 33.33 , respectively). While many of the genera (Table 1) are frequently found as endophytic strains in medicinal plants [32-35], temperate grasses [36], tropical and subtropical rainforests [37] and also as fungi associated with Vitis vinifera [38], some are quite rare: Aplosporella, Ramichloridium, Ephelis, Stachybotrys, Drechslera, Biscogniauxia, Edenia and Thielavia. 
Table 1. Endophytic fungi order, family, genus and host plants with values of relative abundance (RA) for genus, family, and order. Values are represented using a color scale with green representing the smallest value and red the highest value.

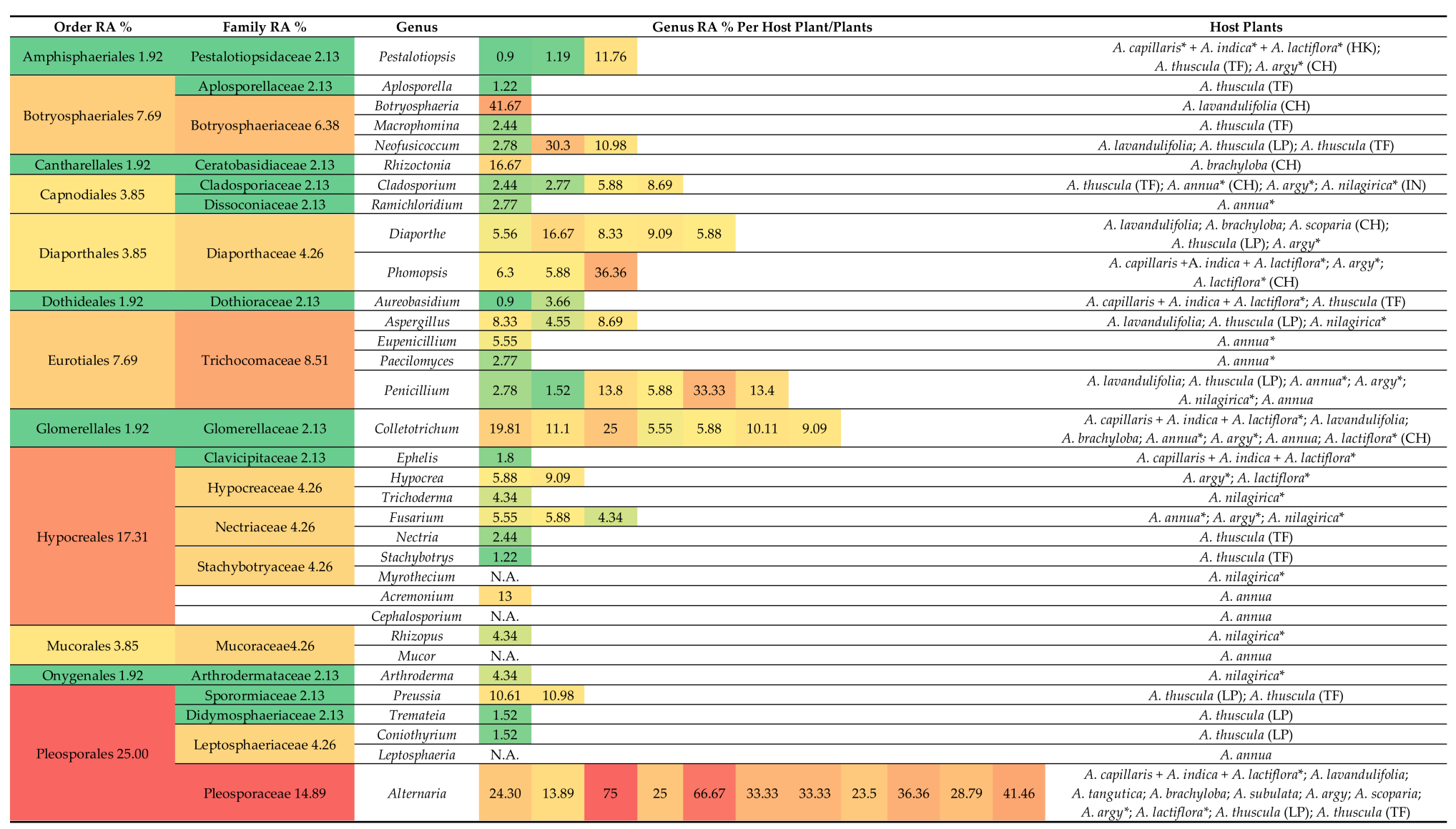


Table 1. Cont.

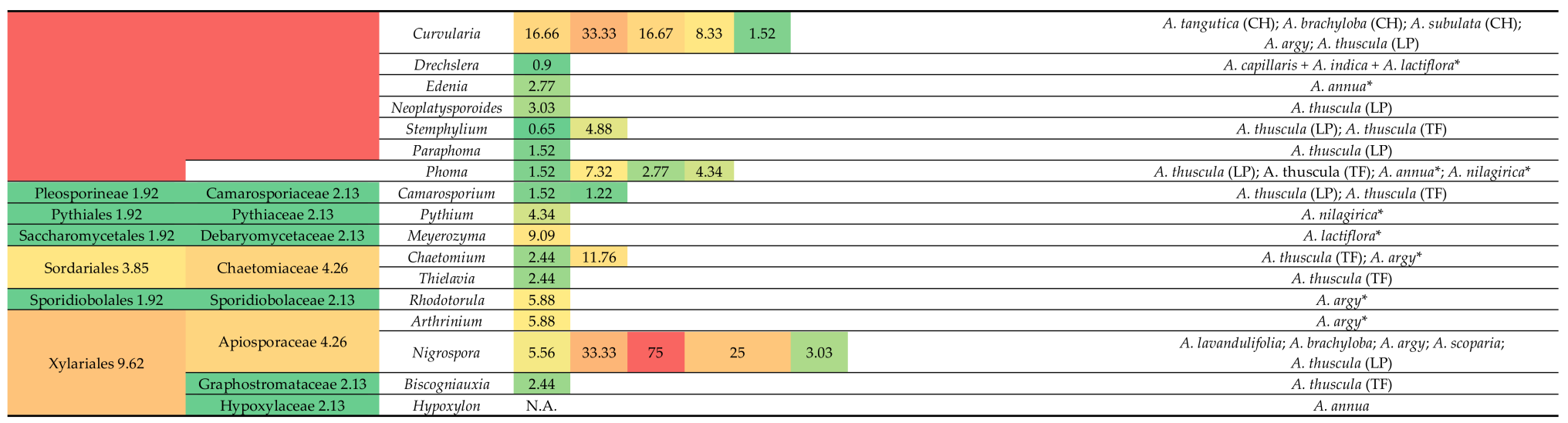

RA \% for genus-calculated as the number of isolates belonging to a genus divided by the total number of individuals. Each value of RA of a genus was calculated for a host (except A. capillaris + A. indica + A. lactiflora, where all three species were considered as one pool as the study did not allow other analysis). For the column RA \%-genus, each cell represents a RA \% value calculated for a host species or more; host species are shown in the right column, separated by ";". Each cell corresponds to a host species in the right column. RA \% for family and order-the number of times that one taxa was found in this survey divided by the total number of taxa (No. of families $=47$, No. of order $=52$ ); although no quantitative data was found for genera such as Hypoxylon, Leptosphaeria, Mucor and Myrothecium; these were used only to calculate the RA of the order/family * - calculation of relative abundance made by the PrK = $\mathrm{HK}=$ Hong Kong island, IN = A. thuscula- [24]; A. argy*-[29]; A. lactiflora*-[39]; A. annu**-[25,40-43]; A. tangutica, A. brachyloba, A. subulata, A. argy, A. lavandulifolia-[23]; A. nilagirica*-[30]. 
Rare and widely abundant species inhabiting Artemisia host plants are different from each other in distribution-abundance relationship (Figure 2). Some of the considered shortcomings of the study are: (i) data is based on purely culture-dependent strains; (ii) the sampling method differs among studies (for instance, in terms of considering two different strains of the same species, there is no standardized method or at least an extended discussion in the literature); and (iii) the lack of information hidden behind the studies which are interested in showing the bioactivity of certain species (or else) without mention on the abundance of strains.

The plotted data shows that the theoretical assumption of a log-normal distribution of the abundance in nature, that is, endophytic fungal communities, where few common taxa have a high abundance and also few taxa are scarcely found, does not fit to the collected data; to name relevant examples: (i) abundant genera (between three and 11 mentions) Alternaria, Nigrospora, Penicillium, Phomopsis, and Neofusicoccum (highest RA \% = 75, 75, 36.4, 33.3, 41.7 and 30, respectively); (ii) least abundant (between two and seven mentions) Pestalotiopsis, Colletotrichum, Diaporthe, Acremonium, Preussia, and Chaetomium (highest RA \% $=11.8,19.8,16.7,13,11$ and 11.8, respectively); and (iii) singleton (with one mention) taxa such as Edenia, Drechslera, Stachybotrys, and Ephelis (RA \% $=2.7,0.9$, 1.2 and 1.8 , respectively). Studies show that the extension of data sampling is directly proportional to the unveiling of the missed taxa [44]. So, the deviations from the log-normal distribution can be used to estimate the inventory size and assume that more rare species would be identified or fall into common categories had there been more sampling and computation.

In this data collection, $71 \%$ of the species were less abundant (between one and eight mentions of strains) with $37.77 \%$ of the species being singleton. The cosmopolitan theory has been previously argued and demonstrations against its postulates (i.e., everything is everywhere) have shown patterns of biogeography for the rare marine microbial biosphere [45]. Furthermore, 59\% of the endophytic fungal species found in tropical forest of Panama were singletons [46] while incidences of endophytic colonization depend on environmental and geographical factors [33]. Isolated ecosystems are known for their specific biodiversity. In this dataset, $28 \%$ of the taxa were isolated from A. thuscula in the Canary Islands while the rest of the genera were found among all regions (China, Hong Kong, India, La Palma, and Tenerife).

Studies on endophytic communities isolated from a plant genus host are encouraged, as besides the implications of the ecosystem, the relations with the host are considered to be specific (chemical, biochemical and physiological levels as well as the biological life cycle). Furthermore, studies have shown a presumable specificity or preference of various endophytic taxa for their hosts [47-49].

This difference in the distribution-abundance relationship between the rare and cosmopolitan taxa raises a question: what determines the exclusive occurrence of singletons; is it sampling size, host, or site? 

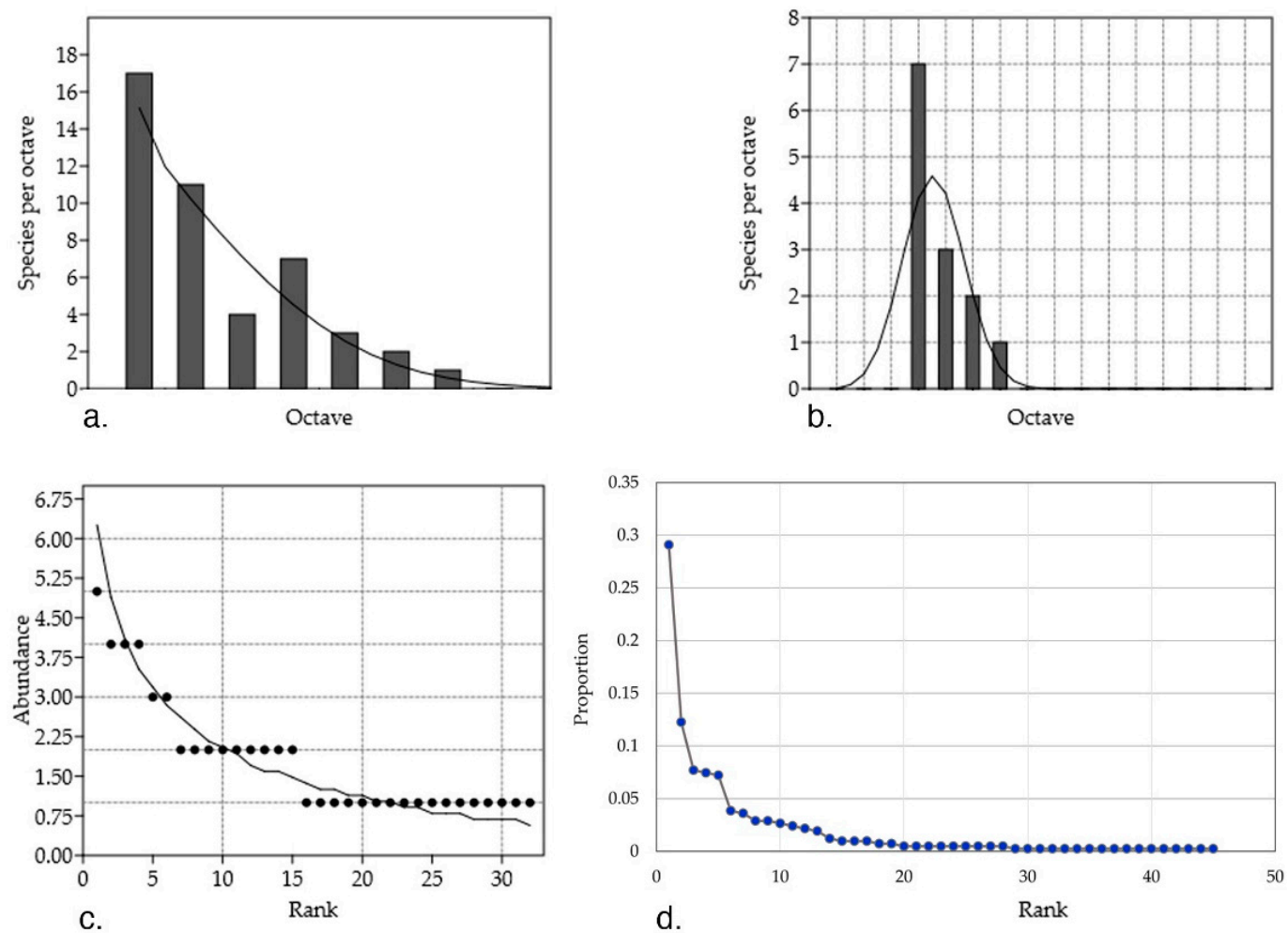

Figure 2. (a) The number of all endophytic fungi (EF) genera plotted in a log-normal distribution (fitted mean $=0.05$, variance $=0.68, \mathrm{chi}^{2}=2.81, p=0.42$ ) for different abundance octaves. The octaves refer to power-of-two abundance classes. The species which theoretically are expected to be present are veiled, as their low abundance prevents them for being represented in the sample. The log-normal distribution was a poor fit to this data due to an overabundance of rare species compared with that expected from the log-normal curve; (b) Abundant EF genera (>eight individuals) predicted by a log-normal distribution (mean $=1.28$, variance $=0.12, \mathrm{chi}^{2}=3.9, p=0.04$ ); a poor fit, as the first interval is dominated by a genus, namely Alternaria; (c) Rare EF species (< eight individuals) predicted by a $\log$ series distribution $\left(\alpha=29.32, \mathrm{x}=0.66, \mathrm{chi}^{2}=0.72, p=0.99\right)$, where many rare genera $(17$ genera with one strain) are represented by a jagged line because predicted values are rounded to the nearest number; (d) Rank abundance curve of the endophytic fungal genera. The slope is extremely steep at the beginning at the curve, meaning that evenness of the community is low, where few of the genera are highly abundant. For $(\mathbf{a}-\mathbf{c})$, only absolute counts, as opposed to relative proportions, were considered, while for $(\mathbf{d})$, relative proportions were considered. Abundance model were calculated with PAST 3.18 software (Øyvind Hammer, Natural History Museum, University of Oslo, Norway) [50].

\section{Biological Activity of Artemisia Endophytes}

Extremely diverse biological activity demonstrated by endophytic fungi associated with Artemisia spp. has been a driving force in the search for active endophytic strains in Artemisia annua [41,51-54]. Two new compounds have been discovered, namely leptosphaerone [43] and leptosphaeric acid [55] which were obtained from Leptosphaeria sp. (Table 2). Fungal endophytes in this plant species were mainly evaluated for their elicitor role in artemisinin production, for their direct production of the molecule or as their role in planta enhancement of artemisinin. Likewise, Lu et al. [40] isolated Colletotrichum sp., an endophytic fungus producing-the plant hormone indole-3-acetic acid (IAA). Plant growth-promoting traits for example increase in plant biomass and chlorophyll content in leaves was demonstrated using a dual symbiotic culture of Piriformospora indica and Azotobacter chroococcum [56]. In addition, a positive influence of $P$. indica filtrate on overall growth and development of micro-propagated plants was observed [57]. Chlorophyll a, chlorophyll b, and carotenoid content were found at the highest rates in Piriformospora indica-associated plants 
compared to the control and autoclaved Piriformospora indica treated plants [58]. Substantial increase in height and leaf area of Artemisia annua was observed in plants treated with fungal elicitor extracts obtained from Cochliobolus lunatus, Colletotrichum gloeosporioides, Acremonium persicinum and Curvularia pallescens [59].

Monitoring the developmental effects of the P. indica endophytic fungus on its Artemisia annua host plant, researchers studied the effect on artemisinin production $[56,57]$. This was proved not only to be an antimalarial drug for human health, but also known to be very effective against a wide spectrum of microorganisms including protozoa, bacteria, fungi and viruses as well as serving as a selective insecticide and phytoalexin [60] and also being used in cancer treatment [61]. In addition, oligo- or polysaccharides derived from endophytic Colletotrichum sp. were used successfully as elicitors to stimulate artemisinin production in Artemisia annua hairy root cultures [53,54,62]. Artemisia annua plants resulted in a 3.47-times increase $(p<0.01)$ in artemisinin production after being treated with Curvularia pallescens fungal elicitor extract [59]. Also, mycelium extracts of Penicillium oxalicum promoted artemisinin biosynthesis in Artemisia annua seedlings [25,63]. Furthermore, the induction of artemisinin biosynthesis by Penicillium oxalicum B4 in A. annua was shown to be strongly dependent on the induced reactive oxygen species (ROS) production [63].

Biological activity against bacteria and fungi was also sought, following the "medicinal plant harbouring active fungal endophytes" model; this time spreading the screening across various species of Artemisia. $\mathrm{Lu}$ et al. [40] isolated and characterised three new metabolites, 6-isoprenylindole-3-carboxylic acid, 3b,5a-dihydroxy-6b-acetoxy-ergosta-7,22-diene, and $3 b, 5 a-d i h y d r o x y-6 b-p h e n y l a c e t y l o x y-e r g o s t a-7,22-d i e n e$, from the culture of the endophyte Colletotrichum sp. (host plant: Artemisia annua). Various inhibitory activities were observed against Candida albicans, Aspergillus niger, and phytopathogenic fungi Gaeumannomyces graminis pvar. tritici, Rhizoctonia cerealis, and Helminthosporium sativum, as well as against the bacteria Bacillus subtilis, Staphylococcus aureus, Micrococcus luteus, and Pseudomonas sp. A strain of Colletotrichum gloeosporioides from Artemisia mongolica produces a novel secondary metabolite named colletotric acid inhibiting growth of Bacillus subtilis, Staphylococcus aureus, and Micrococcus luteus [64]. Three strains of Aspergillus spp. (i.e., SPS-02, SPS-04, and SPS-01) were isolated from Artemisia annua and were found to possess strong antimicrobial activities against the human pathogens Escherichia coli, Staphylococcus aureus and Trichophyton rubrum, and cytotoxic activities [41]. The authors also found an inhibitory effect on Rhizoctonia cerealis with a strain of Mucor sp. SPS-11, and the strongest antimicrobial activities observed against Magnaporthe grisea were exhibited by two strains of Aspergillus fumigatus (SPS-02) and Cephalosporium sp. (SPS-08). The same strain of A. fumigatus produced four ardeemin derivatives with various activities of reversing the multidrug-resistant phenotype in three cancer cell lines [65].

Seven endophytic fungal strains isolated from leaves of Artemisia annua were solvent-extracted and tested against the bacteria Staphylococcus aureus, Streptococcus mutans, Salmonella enterica serotype Typhi, and Bacillus subtilis, and the fungi Malassezia furfur and Candida albicans [66]. Three strains had the broadest range of antimicrobial activity (i.e., inhibition of all tested strains), one strain inhibited only E. coli and S. aureus, and three endophytes were active against three bacterial strains and $M$. furfur. None were active against $C$. albicans. Extracts obtained from cultures of endophytic fungi (i.e., Rhodotorula sp. and Fusarium sp.) isolated from Artemisia argyi proved cytotoxic against liver cancer cell lines (Hep G2) [67]. Similarly, Pestalotiopsis hainanensis was active against all tested cell lines (MCF-7 breast, COLO205 colon, and HL-60 leukemia), while Phomopsis mali and Rhodotorula glutinis inhibited the HL-60 leukemia cell line, Alternaria sp. was active only against the MCF-7 breast cell line, and Colletotrichum gloeosporioides inhibited growth of the COLO205 colon cell line [29].

(i) Five new fungal polyketides and (ii) two known analogues were isolated from EtOAc-extracted biomass of Trichoderma koningiopsis (strain QA-3): (i) ent-koninginin A, 1,6-di-epi-koninginin A, 15-hydroxykoninginin A, 10-deacetylkoningiopisinin D and koninginin $\mathrm{T}$; and (ii) koninginin $\mathrm{L}$ and trichoketide A [68]. Both ent-koninginin A and trichoketide A inhibited E. coli, and the second 
compound also showed antifungal activity against Bipolaris sorokiniana, Ceratobasidium cornigerum, Colletotrichum gloeosporioides, Fusarium graminearum, Fusarium oxysporum, Penicillium digitatum, Physalospora piricola and Valsa mali. Myrothecium rorideum (strain IFB-E012) isolated from stems of Artemisia annua produced lumichrome, a compound with moderate cytotoxicity to the human cell line KB [51]. Furthermore, a new cytotoxic trichothecene macrolide dihydromyrothecine compound was isolated from the same strain [69] together with three new 10,13-cyclotrichothecane-based macrolides [70]. Hypoxylon truncatum, an endophytic fungus isolated from Artemisia annua, yielded two novel cytotoxic benzofluoranthene-based metabolites named daldinone $C$ and daldinone D [42].

Previous studies exhibited antibiotic and antitumor activities provoked by secondary metabolites such as azaphilones, which were demonstrated to be of chemotaxonomic significance in the classification of the Hypoxylon species [71]. Antioxidant phenolic metabolites were also reported to be produced by fungal endophytes inhabiting Artemisia capillaris, Artemisia indica and Artemisia lactiflora [72].

Likewise, 12 endophytic fungi isolated from Artemisia absinthium were tested for their ability to infect grape berries and for their potential to reduce the infection with Botrytis cinerea. Three of the fungal strains reduced both the percentage of infected berries and lesion diameter [73]. Antagonism assays are the preliminary step in these kinds of studies. For instance, Myrchiang et al. [30] proposes as good biocontrol agents of Phytophthora infestans the use of Trichoderma viride, Aspergillus fumigatus, and Penicillium atrovenetum, isolated from Artemisia nilagirica. Liu et al. [52] found 14 fungal endophytes in Artemisia annua which produce antagonistic substances against four phytopathogenic fungi: Fusarium graminearum, Rhizoctonia cerealis, Helminthosporium sativum, and Gerlachia nivalis. Furthermore, inhibitory activities of culture broths were evaluated. Similarly, a series of endophytic fungi from seven species of Artemisia (i.e., Artemisia tangutica, Artemisia brachyloba, Artemisia subulata, Artemisia argyi, Artemisia scoparia, Artemisia lavandulifolia, and Artemisia sp.) were evaluated [23]. It is worth mentioning that both studies found that antagonism assays (i.e., dual culture) do not converge with toxicity assays (i.e., nutrient media amended).

Research on strains isolated from A. annua to pursue their degradation of triclosan, the emerging contaminant in the aqueous and soil environment, resulted in the identification of an active strain, B4, of Penicillium oxalicum [74]. Triclosan was removed from the culture media by fungal degradation with a rate of $97.26 \%$ after one hour of incubation in fungal culture medium $\left(5 \mathrm{mg} \mathrm{L}^{-1}\right)$. Effective results were displayed in nonsterile synthetic wastewater and completion of degradation of triclosan was obtained in two hours. It represents a pioneering study that demonstrated the degradation of the notorious antimicrobial pollutant triclosan.

During the last decade, limited studies have been conducted on bioprospection of the microbiome of Artemisia sp. Nevertheless, its endophytic fungal communities have been a source of 27 novel compounds and 22 already characterised molecules of which 35 were shown to have at least one interesting trait to be further pursued in biotechnology. 
Table 2. Literature review on bioactive endophytic fungi (EF) isolated from species of Artemisia: host species, plant part of isolation, fungal taxa, endophyte isolation method, bioactive compounds/extracts, class of compounds, bioactivity, and references.

\begin{tabular}{|c|c|c|c|c|c|c|c|}
\hline Artemisia Species & Plant Part & EF Taxa & $\begin{array}{l}\text { EF Identification } \\
\text { Method }\end{array}$ & Compound/Extract & Class of Compounds & Bioactivity & Reference \\
\hline A. absinthium & root & $\begin{array}{c}\text { Penicillium spp. } \\
\text { (strains B6C18 and B14C36) }\end{array}$ & N.A. & spore solution $\left(10^{6} \mathrm{~mL}^{-1}\right)$ & N.A. & $\begin{array}{l}\text { Antifungal inhibition of diameter of lesions on } \\
\text { vine berries: } 75 \% \text { and } 91 \%\end{array}$ & [73] \\
\hline \multirow{29}{*}{ А. аппиа } & \multirow{29}{*}{ stem } & Aspergillus spp. & \multirow{4}{*}{ morphology } & \multirow{4}{*}{ ethyl acetate crude extract } & \multirow{4}{*}{ N.A. } & & \multirow{4}{*}{ [41] } \\
\hline & & Mucor spp. & & & & Antibacterial, antifungal & \\
\hline & & Cephalosporium spp. & & & & & \\
\hline & & Fusarium spp. & & & & Antibacterial & \\
\hline & & $\begin{array}{l}\text { Aspergillus terreus } \\
\text { (strain IFB-E030) }\end{array}$ & N.A. & 10-phenyl-[12]-cytochalasins Z17 & Cytochalasan, alkaloids & Cytotoxic $\mathrm{IC}_{50}=26.2 \mu \mathrm{M}$ & [75] \\
\hline & & \multirow{11}{*}{ Colletotrichum sp. } & \multirow{11}{*}{ morphology } & \multirow{2}{*}{$3 \beta$-hydroxy-ergosta-5-ene } & \multirow{2}{*}{ Ergosterol derivatives } & Antifungal \%I $\left(200 \mu \mathrm{g} \mathrm{mL}^{-1}\right): 77-85 \%$ & \multirow{11}{*}{ [40] } \\
\hline & & & & & & Antimicrobial MIC $\left(\mu \mathrm{g} \mathrm{mL}^{-1}\right): 50-75$ & \\
\hline & & & & \multirow{2}{*}{ 3-oxo-ergosta-4,6,8(11),22-tetraene } & \multirow{2}{*}{ Triunsaturated steroids } & Antifungal \% ( $\left(200 \mu \mathrm{g} \mathrm{mL}^{-1}\right): 75 \%$ & \\
\hline & & & & & & Antimicrobial MIC ( $\mu \mathrm{g} \mathrm{mL}^{-1}$ ): $25-75 \%$ & \\
\hline & & & & 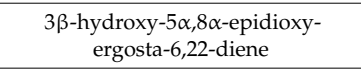 & Ergosterol peroxides & Antimicrobial MIC ( $\left.\mu \mathrm{g} \mathrm{mL}^{-1}\right)$ : 50-75 & \\
\hline & & & & 6-isoprenylindole-3- & \multirow{2}{*}{ indoles } & Antifungal \% $\left(200 \mu \mathrm{g} \mathrm{mL}^{-1}\right): 57-77 \%$ & \\
\hline & & & & carboxylic acid & & Antimicrobial MIC $\left(\mu \mathrm{g} \mathrm{mL}^{-1}\right): 25-75$ & \\
\hline & & & & 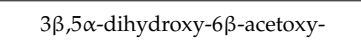 & \multirow{4}{*}{ sterols } & Antifungal \%I (200 $\left.\mu \mathrm{g} \mathrm{mL}^{-1}\right):$ 75-77\% & \\
\hline & & & & ergosta-7,22-diene & & Antimicrobial MIC ( $\left.\mu \mathrm{g} \mathrm{mL}^{-1}\right)$ : $50-100 \%$ & \\
\hline & & & & \multirow{2}{*}{ 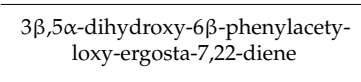 } & & Antifungal \%I $\left(200 \mu \mathrm{g} \mathrm{mL}^{-1}\right): 50-66 \%$ & \\
\hline & & & & & & Antimicrobial MIC $\left(\mu \mathrm{g} \mathrm{mL}^{-1}\right): 50-75$ & \\
\hline & & \multirow{2}{*}{ Hypoxylon trunctatum } & \multirow{13}{*}{$\begin{array}{l}\text { morphology and } 18 \mathrm{~S} \\
\text { rDNA sequence }\end{array}$} & daldinone $\mathrm{C}$ & \multirow{2}{*}{$\begin{array}{c}\text { Benzo[j]fluoranthenes } \\
\text { (polycyclic aromatic hydrocarbons) }\end{array}$} & Cytotoxic $\mathrm{IC}_{50}=49.5 \mu \mathrm{M}$ & \multirow{2}{*}{ [42] } \\
\hline & & & & daldinone $\mathrm{D}$ & & Cytotoxic $\mathrm{IC}_{50}=41 \mu \mathrm{M}$ & \\
\hline & & \multirow{7}{*}{$\begin{array}{l}\text { Myrothecium roridum } \\
\text { (strain IFB-E012) }\end{array}$} & & myrothecine A & \multirow{3}{*}{ Sesquiterpene-based trichothecenes } & Cytotoxic $\mathrm{IC}_{50}=8.5 \mu \mathrm{g} \mathrm{mL}{ }^{-1}$ & \multirow{7}{*}[69,76]{} \\
\hline & & & & myrothecine B & & Cytotoxic $\mathrm{IC}_{50}=0.76 \mu \mathrm{g} \mathrm{mL}^{-1}$ & \\
\hline & & & & myrothecine $\mathrm{C}$ & & Cytotoxic $\mathrm{IC}_{50}=32.21 \mathrm{\mu g} \mathrm{mL}^{-1}$ & \\
\hline & & & & roridin E & Macrocyclic trychothecenes & Cytotoxic $\mathrm{IC}_{50}=0.03 \mu \mathrm{g} \mathrm{mL}^{-1}$ & \\
\hline & & & & mytoxin B & \multirow{3}{*}{ Trychothecene macrolides } & Cytotoxic $\mathrm{IC}_{50}=0.002 \mu \mathrm{g} \mathrm{mL}-1$ & \\
\hline & & & & dihydromyrothecine $\mathrm{C}$ & & Cytotoxic $\mathrm{IC}_{50}=44.48 \mu \mathrm{M}$ & \\
\hline & & & & roritoxin $\mathrm{E}$ & & Cytotoxic IC ${ }_{50}=0.26 \mu \mathrm{g} \mathrm{mL}^{-1}, 10.54 \mu \mathrm{g} \mathrm{mL}^{-1}$ & \\
\hline & & \multirow{4}{*}{ Aspergillus fumigatus } & & 5- $\mathrm{N}$-acetylardeemin & \multirow{4}{*}{$\begin{array}{l}\text { Pyrimidinones (aromatic } \\
\text { heterocyclic diazenes) }\end{array}$} & Cytotoxic RF $=1.5-6 \mu \mathrm{M}$ & \multirow{4}{*}{ [65] } \\
\hline & & & & 5-N-acetyl-15b $\beta$-hydroxyardeemin & & Cytotoxic RF $=2-9.5 \mu \mathrm{M}$ & \\
\hline & & & & 5-N-acetyl-15b-didehydroardeemin & & Cytotoxic RF $=2.5-8 \mu \mathrm{M}$ & \\
\hline & & & & 5-N-acetyl-16 $\alpha$-hydroxyardeemin & & Cytotoxic RF $=1.5-7 \mu \mathrm{M}$ & \\
\hline
\end{tabular}


Table 2. Cont.

\begin{tabular}{|c|c|c|c|c|c|c|c|}
\hline & \multirow{4}{*}{$\begin{array}{c}\text { leaves } \\
\text { Pan }\end{array}$} & Colletotrichum gloeosporioides & \multirow{2}{*}{\multicolumn{2}{|c|}{ 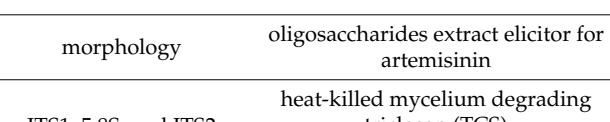 }} & oligosaccharides & increment of artemisinin $=64.29 \%$ & [62] \\
\hline & & Penicillium oxalicum & & & N.A. & max. adsorbing capacity of TCS $=17.60 \mathrm{mg} \mathrm{g}^{-1}$ & {$[74]$} \\
\hline & & Curvularia pallescens & ITS1, 5.8S, and ITS2 & elicitor extract for artemisinin & N.A. & $\begin{array}{l}\text { 2-6\% elicitor extract }(w / v) \text { : artemisinin content }= \\
\text { 1.21-3.47-times more than control }\end{array}$ & [59] \\
\hline & & Cladosporium sp. & morphology & ethyl acetate extract & N.A. & Antibacterial & {$[66]$} \\
\hline & \multirow{3}{*}{ stem } & $\begin{array}{l}\text { Paraphaeosphaeria nolinae } \\
\text { (strain IFB-E011) }\end{array}$ & \multirow{3}{*}{ N.A. } & paranolin & $\begin{array}{l}\text { polycyclic aromatic compounds } \\
\text { (xanthene-based) }\end{array}$ & Cytotoxic $\mathrm{IC}_{50}$ values $>50 \mu \mathrm{g} \mathrm{mL}{ }^{-1}$ & [77] \\
\hline & & \multirow[t]{2}{*}{ Phomopsis sp. } & & $\begin{array}{l}\text { crude EtOAc extract }=\mathrm{BB} 1 \text {, fraction } \\
\mathrm{Hex} / \mathrm{EtOAc} / \mathrm{MeOH}=\mathrm{BB} 4 \\
\text { fractions } \mathrm{MeOH}=\mathrm{BB} 8, \mathrm{BB} 9, \mathrm{BB} 10\end{array}$ & N.A. & \multirow{2}{*}{$\begin{array}{c}\text { Cytotoxic: } \mathrm{IC}_{50}\left(\mu \mathrm{g} \mathrm{mL}^{-1}\right) \mathrm{BB} 1=17.11, \\
\mathrm{BB}=0.7 ; \% \mathrm{I}(20 \mu \mathrm{\mu g} / \mathrm{mL}) \mathrm{BB}=1.97, \mathrm{BB}=0.53, \\
\mathrm{BB} 10=52.98\end{array}$} & \multirow[t]{2}{*}{ [78] } \\
\hline & & & & tyrosol (purified from BB10) & Phenolic compounds & & \\
\hline \multirow{13}{*}{ A. argyi } & \multirow{9}{*}{ N.A. } & Phomopsis sp. (strain H31) & \multirow{9}{*}{ ITS1, 5.8S, and ITS2 } & \multirow{9}{*}{$\begin{array}{c}\text { ethyl acetate + ethyl acetate/water } \\
\text { extract }\end{array}$} & \multirow{9}{*}{ N.A. } & $\begin{aligned} \text { Antifungal \% }\left(1 \mathrm{mg} \mathrm{mL}^{-1}\right) & =34.57 ; \text { Cytotoxic } \\
\% \mathrm{I}\left(20 \mu \mathrm{gL}^{-1}\right) & =81.69\end{aligned}$ & \multirow{9}{*}{29} \\
\hline & & Cladosporium sp. (strain H23) & & & & Antifungal \% $\left(1 \mathrm{mg} \mathrm{mL}^{-1}\right)=23.46$ & \\
\hline & & Chaetomium sp. (strain H40) & & & & Antibacterial & \\
\hline & & Penicillium sp. (strain H9) & & & & Antibacterial & \\
\hline & & Pestalotiopsis sp. (strain H14) & & & & $\begin{array}{c}\text { Antibacterial;Cytotoxic \% }\left(20 \mu \mathrm{g} \mathrm{mL}^{-1}\right)=53.47, \\
71.43,97.03\end{array}$ & \\
\hline & & Diaporthe sp. (strain H26) & & & & Antibacterial & \\
\hline & & Trichoderma sp. (strain H17) & & & & Antibacterial & \\
\hline & & Rhodotorula sp. (strain H13) & & & & Cytotoxic \% $(20 \mu \mathrm{g} \mathrm{mL}-1)=16.41,23.56,78.28$ & \\
\hline & & Colletotrichum sp. (strain $\mathrm{H} 42$ ) & & & & Cytotoxic \% $\left(20 \mu g \mathrm{~mL}^{-1}\right)=11.22,26.95,71.99$ & \\
\hline & \multirow{4}{*}{ stem } & Nigrospora sphaerica & $\begin{array}{c}\text { morphology and ITS1, } \\
5.8 S \text {, and ITS2 }\end{array}$ & ethyl acetate crude extract & N.A. & Antifungal \%I $\left(1 \mathrm{mg} \mathrm{mL}^{-1}\right): 48.37,11.94,24.92$ & [23] \\
\hline & & \multirow{3}{*}{$\begin{array}{l}\text { Trichoderma koningiopsis } \\
\text { (strain QA-3) }\end{array}$} & \multirow{3}{*}{ ITS1, 5.8S, and ITS2 } & ent-koninginin A & \multirow{3}{*}{ Tricyclic polyketides } & $\begin{array}{l}\text { Antifungal MIC }\left(\mu \mathrm{g} \mathrm{mL}^{-1}\right): 8-64 \\
\text { Antibacterial MIC }\left(\mu \mathrm{gLL}^{-1}\right): 8-64\end{array}$ & \multirow{3}{*}{ [68] } \\
\hline & & & & 1,6-di-epi-koninginin A & & $\begin{array}{c}\text { Antifungal MIC }\left(\mu \mathrm{g} \mathrm{mL}^{-1}\right): 64 \\
\text { Antibacterial MIC }(\mu \mathrm{g} \mathrm{mL}-1): 32-64\end{array}$ & \\
\hline & & & & 15-hydroxykoninginin A & & $\begin{array}{c}\text { Antifungal MIC }(\mu \mathrm{g} \mathrm{mL}-1): 64 \\
\text { Antibacterial MIC }\left(\mu \mathrm{g} \mathrm{mL}^{-1}\right): 16-64\end{array}$ & \\
\hline
\end{tabular}


Table 2. Cont.

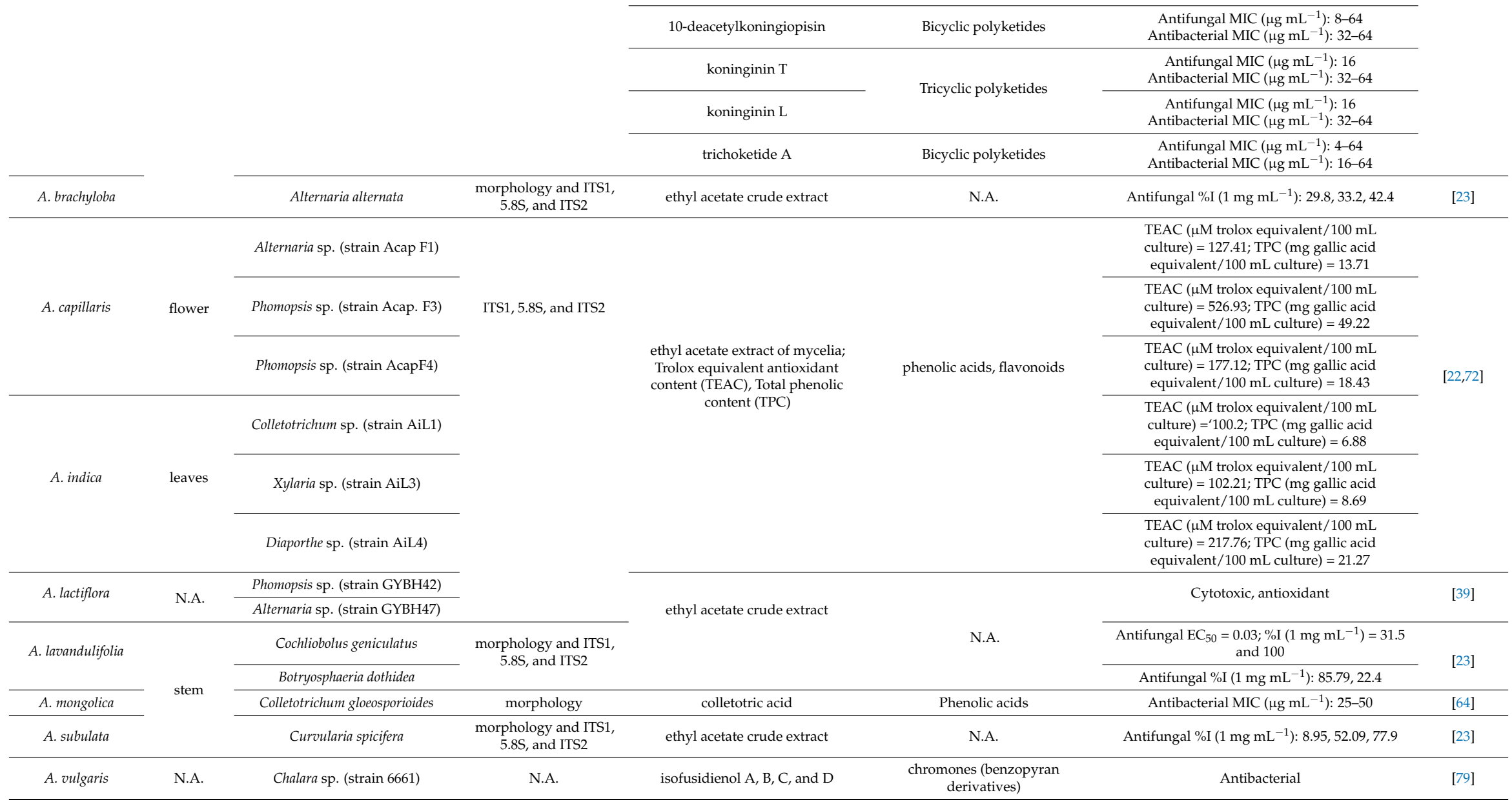

EF-endophytic fungi; MIC-minimum inhibitory concentration; \% —-percentage of inhibition, TEAC—-trolox equivalent antioxidant capacity; TPC—-total phenolic content; where both $\% \mathrm{I}$ and $\mathrm{EC}_{50}$ are presented, it means that results were expressed as such depending on the pathogenic strains tested and conditions employed. InChI keys are provided as supplementary materials. 


\section{Conclusions}

Artemisia is a large genus of perennial and annual plants with species producing a variety of interesting and active compounds. The early exploration of its endophytic communities indicates diversity with promise of further significant biological activity. Research of the endophytes associated with the genus has revealed both cosmopolitan and rare endophytic species with highly studied chemical profiles, active molecules, and developed in vitro culture techniques.

Supplementary Materials: The following are available online at http:/ /www.mdpi.com/2309-608X/4/2/53/s1. Author Contributions: A.C. and R.C. conceived, designed, and wrote the manuscript.

Acknowledgments: We thank Kanika Chowdhary (TERI Institute, New Delhi) for reviewing the English language of the manuscript. We deeply appreciate Matias Reina Artiles (IPNA-CSIC, Tenerife, Spain) and two unknown reviewers whose valuable considerations have improved this survey. Also, we are grateful to Alin Gayraud who helped with the graphical abstract.

Conflicts of Interest: The authors declare no conflict of interest. The founding sponsors had no role in the design of the study; in the collection, analyses, or interpretation of data; in the writing of the manuscript; and in the decision to publish the results.

\section{References}

1. Haider, F.; Dwivedi, P.D.; Naqvi, A.A.; Bagchi, G.D. Essential oil composition of Artemisia vulgaris harvested at different growth periods under indo-gangetic plain conditions. J. Essent. Oil Res. 2003, 15, 376-378. [CrossRef]

2. Judžentien, A.; Buzelyte, J. Chemical composition of essential oils of Artemisia vulgaris L. (mugwort) from North Lithuania. Chemija 2006, 17, 12-15.

3. Blagojević, P.; Radulović, N.; Palić, R.; Stojanović, G. Chemical composition of the essential oils of Serbian wild-growing Artemisia absinthium and Artemisia vulgaris. J. Agric. Food Chem. 2006, 54, 4780-4789. [CrossRef] [PubMed]

4. Abiri, R.; Silva, A.L.M.; de Mesquita, L.S.S.; de Mesquita, J.W.C.; Atabaki, N.; de Almeida, E.B.; Shaharuddin, S.M. Towards a better understanding of Artemisia vulgaris: Botany, phytochemistry, pharmacological and biotechnological potential. Food Res. Int. 2018. [CrossRef]

5. Koul, B.; Taak, P. The Artemisia Genus: A Review on Traditional Uses, Phytochemical Constituents, Pharmacological Properties and Germplasm Conservation. J. Glycom. Lipidom. 2018, 7, 1-7. [CrossRef]

6. Pandey, A.K.; Singh, P. The Genus Artemisia: A 2012-2017 Literature Review on Chemical Composition, Antimicrobial, Insecticidal and Antioxidant Activities of Essential Oils. Medicines 2017, 4, 68. [CrossRef] [PubMed]

7. Tabari, M.A.; Youssefi, M.R.; Benelli, G. Eco-friendly control of the poultry red mite, Dermanyssus gallinae (Dermanyssidae), using the $\alpha$-thujone-rich essential oil of Artemisia sieberi (Asteraceae): Toxic and repellent potential. Parasitol. Res. 2017, 116, 1545-1551. [CrossRef] [PubMed]

8. Zhou, J.; Zou, K.; Zhang, W.; Guo, S.; Liu, H.; Sun, J.; Li, J.; Huang, D.; Wu, Y.; Du, S.; et al. Efficacy of Compounds Isolated from the Essential Oil of Artemisia lavandulaefolia in Control of the Cigarette Beetle, Lasioderma serricorne. Molecules 2018, 23, 343. [CrossRef] [PubMed]

9. Lopez-Lazaro, M. Distribution and Biological Activities of the Flavonoid Luteolin. Mini-Rev. Med. Chem. 2009, 9, 31-59. [CrossRef] [PubMed]

10. Lee, J.K. Anti-inflammatory effects of eriodictyol in lipopolysaccharidestimulated raw 264.7 murine macrophages. Arch. Pharm. Res. 2011, 34, 671-679. [CrossRef] [PubMed]

11. Bucolo, C.; Leggio, G.M.; Drago, F.; Salomone, S. Eriodictyol prevents early retinal and plasma abnormalities in streptozotocin-induced diabetic rats. Biochem. Pharmacol. 2012, 84, 88-92. [CrossRef] [PubMed]

12. Lee, S.J.; Chung, H.Y.; Maier, C.G.; Wood, A.R.; Dixon, R.; Mabry, T. Estrogenic flavonoids from Artemisia vulgaris L. J. Agric. Food Chem. 1998, 46, 3325-3329. [CrossRef]

13. Ikram, N.K.B.K.; Simonsen, H.T. A Review of Biotechnological Artemisinin Production in Plants. Front. Plant Sci. 2017, 8, 1-10. [CrossRef] [PubMed] 
14. Oliveira, C.B.S.; Meurer, Y.S.R.; Oliveira, M.G.; Medeiros, W.M.T.Q.; Silva, F.O.N.; Brito, A.C.F.; Pontes, D.L.; Andrade-Neto, V. Comparative study on the antioxidant and anti-Toxoplasma activities of vanillin and its resorcinarene derivative. Molecules 2014, 19, 5898-5912. [CrossRef] [PubMed]

15. Aziz, A.T.; Alshehri, M.A.; Panneerselvam, C.; Murugan, K.; Trivedi, S.; Mahyoub, J.A.; Hassan, M.M.; Maggi, F.; Sut, S.; Dall'Aqua, S.; et al. The desert wormwood (Artemisia herba-alba)_From Arabian folk medicine to a source of green and effective nanoinsecticides against mosquito vectors. J. Photochem. Photobiol. B Biol. 2018, 180, 225-234. [CrossRef] [PubMed]

16. D'Addabbo, T.; Argentieri, M.P.; Radicci, V.; Grassi, F.; Avato, P. Artemisia annua compounds have potential to manage root-knot and potato cyst nematodes. Ind. Crops Prod. 2017, 108, 195-200. [CrossRef]

17. Julio, L.F.; González-Coloma, A.; Burillo, J.; Diaz, C.E.; Andrés, M.F. Nematicidal activity of the hydrolate byproduct from the semi industrial vapor pressure extraction of domesticated Artemisia absinthium against Meloidogyne javanica. Crop Prot. 2017, 94, 33-37. [CrossRef]

18. Chengala, L. Botanical pesticides-A major alternative to chemical pesticides: A review. Int. J. Life Sci. 2017, 5, 722-729.

19. Esmaeily, M.; Bandani, A.; Zibaee, I.; Sharifian, I.; Zare, S. Sublethal effects of Artemisia annua L. and Rosmarinus officinalis L. essential oils on life table parameters of Tetranychus urticae (Acari: Tetranychidae). Persian J. Acarol. 2017, 6, 39-52.

20. Sainz, P.; Cruz-Estrada, Á.; Díaz, C.E.; González-Coloma, A. The genus Artemisia: Distribution and phytochemistry in the Iberian Peninsula and the Canary and Balearic Islands. Phytochem. Rev. 2017, 16, 1023-1043. [CrossRef]

21. Royal Botanic Gardens K and MBG. The Plant List 2010. Available online: http://www.theplantlist.org/tpl/ search?q=artemisia (accessed on 3 February 2017).

22. Huang, W.Y.; Cai, Y.Z.; Surveswaran, S.; Hyde, K.D.; Corke, H.; Sun, M. Molecular phylogenetic identification of endophytic fungi isolated from three Artemisia species. Fungal Divers. 2009, 36, 69-88.

23. Cosoveanu, A.; Hernandez, M.; Iacomi-Vasilescu, B.; Zhang, X.; Shu, S.; Wang, M.; Cabrera, R. Fungi as endophytes in Chinese Artemisia spp.: Juxtaposed elements of phylogeny, diversity and bioactivity. Mycosphere 2016, 7, 102-117. [CrossRef]

24. Cosoveanu, A.; Rodriguez Sabina, S.; Cabrera, R. Fungi as endophytes in Artemisia thuscula: Juxtaposed elements of diversity and phylogeny. J. Fungi 2018, 4, 17. [CrossRef] [PubMed]

25. Yuan, Z.L.; Chen, Y.C.; Ma, X.J. Symbiotic fungi in roots of Artemisia annua with special reference to endophytic colonizers. Plant Biosyst. 2011, 145, 495-502. [CrossRef]

26. Ofek-lalzar, M.; Gur, Y.; Ben-Moshe, S.; Sharon, O.; Kosman, E.; Mochli, E.; Sharon, A. Diversity of fungal endophytes in recent and ancient wheat ancestors of Triticum dicoccoides and Aegilops sharonensis. FEMS Microbiol. Ecol. Adv. 2016, 92, 1-26. [CrossRef]

27. Kernaghan, G.; Mayerhofer, M.; Griffin, A. Fungal endophytes of wild and hybrid Vitis leaves and their potential for vineyard biocontrol. Can. J. Microbiol. 2017, 63, 583-595. [CrossRef] [PubMed]

28. Tang, A.M.C.; Hyde, K.D.; Corlett, R.T. Diversity of fungi on wild fruits in Hong Kong. Fungal Divers. 2003, 14, 165-185.

29. Qian, Y.; Kang, J.; Geng, K.; Wang, L.; Lei, B. Endophytic fungi from Artemisia argyi Levl. et Vant. and their bioactivity. Chiang Mai J. Sci. 2014, 41, 910-921.

30. Myrchiang, P.; Dkhar, M.S.; Devi, H.R. Studies on endophytic fungi associated with medicinally important aromatic plant Artemisia nilagirica (C.B. Clarke) Pamp. and their antagonistic activity against Phytophthora infestans. J. Adv. Lab. Res. Biol. 2014, 5, 112-119.

31. Cosoveanu, A.; Da Silva, E.; Gimenez Marino, C.; Nunez Trujillo, G.; Gonzalez Coloma, A.; Frias Viera, I.; Cabrera, R. Artemisia thuscula Cav.: Antibacterial, antifungal activity of the plant extracts and associated endophytes. J. Hortic. For. Biotechnol. 2012, 16, 87-90.

32. Gautam, A.K. Diversity of fungal endophytes in some medicinal plants of Himachal Pradesh, India. Arch. Phytopathol. Plant Prot. 2014, 47, 537-544. [CrossRef]

33. Chowdhary, K.; Kaushik, N. Fungal endophyte diversity and bioactivity in the Indian medicinal plant Ocimum sanctum Linn. PLoS ONE 2015, 10, 1-25. [CrossRef] [PubMed]

34. Tan, X.; Zhou, Y.; Zhou, X.; Xia, X.; Wei, Y.; He, L.; Tang, H.; Yu, L. Diversity and bioactive potential of culturable fungal endophytes of Dysosma versipellis; a rare medicinal plant endemic to China. Sci. Rep. 2018, 8, 5929. [CrossRef] [PubMed] 
35. Nalini, M.S.; Sunayana, N.; Prakash, H.S. Endophytic Fungal Diversity in Medicinal Plants of Western Ghats, India. Int. J. Biodivers. 2014, 2014, 1-9. [CrossRef]

36. Sánchez Márquez, S.; Bills, G.F.; Herrero, N.; Zabalgogeazcoa, Í. Non-systemic fungal endophytes of grasses. Fungal Ecol. 2012, 5, 289-297. [CrossRef]

37. Banerjee, D. Endophytic fungal diversity in tropical and subtropical plants. Res. J. Microbiol. 2011, 6, 54-62. [CrossRef]

38. Casieri, L.; Hofstetter, V.; Viret, O.; Gindro, K. Fungal communities in the wood of different cultivars of young Vitis vinifera plants. Phytopathol. Mediterr. 2009, 48, 73-83. [CrossRef]

39. Qian, Y.; Kang, J.; Lei, B.; Wang, L.; Huang, Y. Screening and taxonomic identification of endophytic fungi with antitumor and antioxidant activities from Artemisia lactiflora. China J. Chin. Mater. Med. 2014, 39, 438-441.

40. Lu, H.; Zou, W.X.; Meng, J.C.; Hu, J.; Tan, R.X. New bioactive metabolites produced by Colletotrichum sp., an endophytic fungus in Artemisia annua. Plant Sci. 2000, 151, 67-73. [CrossRef]

41. Zhang, H.; Bai, X.; Wu, B. Evaluation of antimicrobial activities of extracts of endophytic fungi from Artemisia annua. Bangladesh J. Pharmacol. 2012, 7, 120-123. [CrossRef]

42. Gu, W.; Ge, H.M.; Song, Y.C.; Ding, H.; Zhu, H.L.; Zhao, X.A.; Tan, R.X. Cytotoxic benzo[j]fluoranthene metabolites from Hypoxylon truncatum IFB-18, an endophyte of Artemisia annua. J. Nat. Prod. 2007, 70, 114-117. [CrossRef] [PubMed]

43. Liu, J.Y.; Liu, C.H.; Zou, W.X.; Tan, R.X. Leptosphaerone, a metabolite with a novel skeleton from Leptosphaeria sp. IV403, an endophytic fungus in Artemisia annua. Helv. Chim. Acta 2002, 85, 2662-2667. [CrossRef]

44. Wilco, E.P.; Verberk, E.P. Explaining general patterns in species abundance and distributions. Nat. Educ. Knowl. 2011, 3, 38.

45. Galand, P.E.; Casamayor, E.O.; Kirchman, D.L.; Lovejoy, C. Ecology of the rare microbial biosphere of the Arctic Ocean. Proc. Natl. Acad. Sci. USA 2009, 106, 22427-22432. [CrossRef] [PubMed]

46. Arnold, A.E.; Mejia, L.C.; Kyllo, D.; Rojas, E.I.; Maynard, Z.; Robbins, N.; Herre, E.A. Fungal endophytes limit pathogen damage in a tropical tree. Proc. Natl. Acad. Sci. USA 2003, 100, 15649-15654. [CrossRef] [PubMed]

47. Dastogeer, K.M.G.; Li, H.; Sivasithamparam, K.; Jones, M.G.K.; Wylie, S.J. Host Specificity of Endophytic Mycobiota of Wild Nicotiana Plants from Arid Regions of Northern Australia. Microb. Ecol. 2018, 75, 74-87. [CrossRef] [PubMed]

48. Sun, X.; Ding, Q.; Hyde, K.D.; Guo, L.D. Community structure and preference of endophytic fungi of three woody plants in a mixed forest. Fungal Ecol. 2012, 5, 624-632. [CrossRef]

49. Zhou, D.; Hyde, K.D. Host specificity, hos exclusivity and host-recurrence in saprobic fungi. Mycol. Res. 2001, 105, 1449-1457. [CrossRef]

50. Hammer, Ø.; Harper, D.A.T.; Ryan, P.D. PAST: Paleontological statistics software package for education and data analysis. Palaeontol. Electron. 2001, 4, 9.

51. Li, S.; Shi, D.H.; Song, Y.C.; Tan, R.X. Chemical constituents of liquid culture of endophyte IFB-E012 in Artemisia annua. Chin. J. Nat. Med. 2009, 7, 354-356. [CrossRef]

52. Liu, C.H.; Zou, W.X.; Lu, H.; Tan, R.X. Antifungal activity of Artemisia annua endophyte cultures against phytopathogenic fungi. J. Biotechnol. 2001, 88, 277-282. [CrossRef]

53. Wang, J.W.; Zhang, Z.; Tan, R.X. Stimulation of artemisinin production in Artemisia annua hairy roots by the elicitor from the endophytic Colletotrichum sp. Biotechnol. Lett. 2001, 23, 857-860. [CrossRef]

54. Wang, J.W.; Zheng, L.P.; Tan, R.X. The preparation of an elicitor from a fungal endophyte to enhance artemisinin production in hairy root culture of Artemisia annua L. Chin. J. Biotechnol. 2006, 22, 829-834.

55. Liu, J.Y.; Liu, C.H.; Zou, W.X.; Tan, R.X. Leptosphaeric acid, a metabolite with a novel carbon skeleton from Leptosphaeria sp. IV403, an endophytic fungus in Artemisia annua. Helv. Chim. Acta 2003, 86, 657-660. [CrossRef]

56. Arora, M.; Saxena, P.; Choudhary, D.K.; Abdin, M.Z.; Varma, A. Dual symbiosis between Piriformospora indica and Azotobacter chroococcum enhances the artemisinin content in Artemisia annua L. World J. Microbiol. Biotechnol. 2016, 32, 19. [CrossRef] [PubMed] 
57. Baishya, D.; Deka, P.; Kalita, M.C. In vitro co-cultivation of Piriformospora indica filtrate for improve biomass productivity in Artemisia annua (L.). Symbiosis 2015, 66, 37-46. [CrossRef]

58. Jogawat, A.; Saha, S.; Bakshi, M.; Dayaman, V.; Kumar, M.; Dua, M.; Varma, M.; Oelmuller, R.; Tuteja, N.; Johri, A.K. Piriformospora indica rescues growth diminution of rice seedlings during high salt stress. Plant Signal Behav. 2013, 8, e26891. [CrossRef]

59. Hussain, M.; Mahajan, V.; Rather, I.A.; Awasthi, P.; Chouhan, R.; Dutt, P.; Sharma, Y.P.; Bedi, Y.S.; Gandhi, S.G. Isolation and identification of growth promoting endophytic fungi from Artemisia annua L. and its effects on artemisinin content. Trends Phytochem. Res. 2017, 1, 207-214.

60. Jessing, K.K.; Duke, S.O.; Cedergreeen, N. Potential Ecological Roles of Artemisinin Produced by Artemisia annua L. J. Chem. Ecol. 2014, 40, 100-117. [CrossRef] [PubMed]

61. Das, A.K. Anticancer effect of Antimalarial artemisinin compounds. Ann. Med. Health Sci. Res. 2015, 5, 93-102. [CrossRef] [PubMed]

62. Wang, J.W.; Xia, Z.H.; Tan, R.X. Elicitation on Artemisinin Biosynthesis in Artemisia annua Hairy Roots by the Oligosaccharide extract from the Endophytic Colletotrichum sp. B501. Acta Bot. Sin. 2002, 44, 1233-1238.

63. Zheng, L.P.; Tian, H.; Yuan, Y.F.; Wang, J.W. The influence of endophytic Penicillium oxalicum B4 on growth and artemisinin biosynthesis of in vitro propagated plantlets of Artemisia annua L. Plant Growth Regul. 2016, 80, 93-102. [CrossRef]

64. Zou, W.X.; Meng, J.C.; Lu, H.; Chen, G.X.; Shi, G.X.; Zhang, T.Y.; Tan, R.X. Metabolites of Colletotrichum gloeosporioides, an endophytic fungus in Artemisia mongolica. J. Nat. Prod. 2000, 63, 1529-1530. [CrossRef] [PubMed]

65. Zhang, H.W.; Ying, C.; Tang, Y.F. Four ardeemin analogs from endophytic Aspergillus fumigatus SPS-02 and their reversal effects on multidrug-resistant tumor cells. Chem. Biodivers. 2014, 11, 85-91. [CrossRef] [PubMed]

66. Purwantini, I.; Wahyono, M.; Ratna, A. Isolation of endophytic fungi from Artemisia annua, L and identification of their antimicrobial compound using bioautography method. Int. J. Phrmacy Pharm. Sci. 2015, 7, 95-99.

67. Hsieh, P.W.; Hsu, L.C.; Lai, C.H.; Wu, C.C.; Hwang, T.L.; Lin, Y.K.; Wu, Y.C. Evaluation of the bioactivities of extracts of endophytes isolated from Taiwanese herbal plants. World J. Microbiol. Biotechnol. 2009, 25, 1461-1469. [CrossRef]

68. Shi, X.S.; Wang, D.J.; Li, X.M.; Li, H.L.; Meng, L.H.; Li, X.; Pi, Y.; Zhou, X.W.; Wang, B.G. Antimicrobial polyketides from Trichoderma koningiopsis QA-3, an endophytic fungus obtained from the medicinal plant Artemisia argyi. RSC Adv. 2017, 7, 51335-51342. [CrossRef]

69. Shen, L.; Zhu, L.; Tan, Q.; Wan, D.; Xie, J.; Peng, J. New cytotoxic trichothecene macrolide epimers from endophytic Myrothecium roridum IFB-E012. J. Antibiot. 2016, 69, 652-655. [CrossRef] [PubMed]

70. Shen, L.; Jiao, R.H.; Ye, Y.H.; Wang, X.T.; Xu, C.; Song, Y.C.; Zhu, H.L.; Tan, R.X. Absolute configuration of new cytotoxic and other bioactive trichothecene macrolides. Chem. A Eur. J. 2006, 12, 5596-5602. [CrossRef] [PubMed]

71. Quang, D.N.; Hashimoto, T.; Nomura, Y.; Wollweber, H.; Hellwig, V.; Fournier, J.; Staedler, M.; Asakawa, Y. Cohaerins A and B, azaphilones from the fungus Hypoxylon cohaerens, and comparison of HPLC-based metabolite profiles in Hypoxylon sect. Annulata. Phytochemistry 2005, 66, 797-809. [CrossRef] [PubMed]

72. Huang, W.; Cai, Y.Z.; Xing, J.; Corke, H.; Sun, M. A potential antioxidant resource: Endophytic fungi from medicinal plants. Econ. Bot. 2007, 61, 14-30. [CrossRef]

73. Noumeur, S.R.; Mancini, V.; Romanazzi, G. Activity of endophytic fungi from Artemisia absinthium on Botrytis cinerea. Acta Hortic. 2016, 1144, 101-104. [CrossRef]

74. Tian, H.; Ma, Y.J.; Li, W.Y.; Wang, J.W. Efficient degradation of triclosan by an endophytic fungus Penicillium oxalicum B4. Environ. Sci. Pollut. Res. 2018. [CrossRef] [PubMed]

75. Zhang, H.W.; Zhang, J.; Hu, S.; Zhang, Z.J.; Zhu, C.J.; Ng, S.W.; Tan, R.W. Ardeemins and cytochalasins from Aspergillus terreus residing in Artemisia annua. Planta Med. 2010, 76, 1616-1621. [CrossRef] [PubMed]

76. Shen, L.; Wang, J.S.; Shen, H.J.; Song, Y.C.; Tan, R.X. A new cytotoxic trichothecene macrolide from the endophyte Myrothecium roridum. Planta Med. 2010, 76, 1004-1006. [CrossRef] [PubMed]

77. Ge, H.M.; Song, Y.C.; Chen, J.R.; Hu, S.; Wu, J.Y.; Tan, R.X. Paranolin: A new xanthene-based metabolite from Paraphaeosphaeria nolinae. Helv. Chim. Acta 2006, 89, 502-506. [CrossRef] 
78. Ngankaranatikarn, P.; Chuanasa, T.; Sriubolmas, N.; Suwanborirux, K. Antileukemic activity and secondary metabolites of an endophytics fungus Phomopsis sp. from Artemisia annua. Thai J. Pharm. Sci. 2013, 38, 195-198.

79. Lösgen, S.; Magull, J.; Schulz, B.; Draeger, S.; Zeeck, A. Isofusidienols: Novel chromone-3-oxepines produced by the endophytic fungus Chalara sp. Eur. J. Org. Chem. 2008, 698-703. [CrossRef]

(c) 2018 by the authors. Licensee MDPI, Basel, Switzerland. This article is an open access article distributed under the terms and conditions of the Creative Commons Attribution (CC BY) license (http:/ / creativecommons.org/licenses/by/4.0/). 